\title{
Pengaruh Ukuran Perusahaan Dan Corporate Governance Terhadap Manajemen Laba Di Industri Perbankan Indonesia
}

Studi Kasus Pada Industri Perbankan Yang Terdaftar Di BEI Pada Tahun 2016-2018

\author{
Karina dan Sutarti \\ Program Studi Akuntansi, Institut Bisnis dan Informatika Kesatuan \\ EMail: karina@ibik.ac.id
}

Submitted: JANUARI 2020

Accepted: MARET 2021

\begin{abstract}
The purpose of this research is to provide empirical evidence of the affect of ownership concetration, firms size, and corporate governance mechanisms on earnings management. Ownership concetration was measure by the biggest stock of individual or organization, firms size was measure by natural logaritma of net assets, and corporate governance mechanisms were measure by three variabels (composition of board of commisioner, audit quality were measure by industry specialize audit firm, and composition of audit committee). Earnings management was measure by discretionary accruals use Modified Jones Method. The population of this research is 41 companies in the banking sector which were listed in Indonesian Stock Exchange (IDX). The research data were collected from banking companies financial statement for the period of 2016 to 2018. Based on purposive sampling method. The reseacrh hypotesis were tested using multiple regression analysis. The results of this research show that firm size, firm of commissioner and proportion of commissioner have significant relationships with earnings management. Next, variables composition of board of commissioner, ownership concetration and specialize audit firm have no significant relationship with earnings management.
\end{abstract}

Keywords: ownership concetration, firms size, corporate governance, earnings management

\begin{abstract}
ABSTRAK
Penelitian ini bertujuan untuk memperoleh bukti empiris tentang pengaruh konsentrasi kepemilikan, ukuran perusahaan, dan mekanisme corporate governance terhadap manajemen laba. Konsentrasi kepemilikan diukur dengan jumlah saham terbesar yang dimiliki individu atau kelompok, ukuran perusahaan diukur dengan menggunakan natural logaritma dari total aktiva perusahaan dan mekanisme corporate governance diukur menggunakan tiga variabel (komposisi dewan komisaris, kualitas audit yang diproksi dengan spesialisasi industri auditor, dan komposisi komite audit). Manajemen laba diukur dengan discretionary accruals menggunakan Modified Jones Model. Populasi pada penelitian ini adalah 45 perusahaan bank yang terdaftar di Bursa Efek Indonesia tahun 2016-2018. Data penelitian diperoleh dari laporan keuangan perusahaan manufaktur periode tahun 2016-2018. Berdasarkan metode purposive sampling, sampel yang diperoleh sebanyak 41 perusahaan. Hipotesis dalam penelitian ini diuji menggunakan analisis regresi berganda. Hasil analisis menunjukkan bahwa variabel yang mempunyai pengaruh signifikan terhadap manajemen laba adalah ukuran perusahaan, ukuran dewan komisaris dan, proporsi dewan komisaris. Selanjutnya, variabel independen akuntan public, kepemilikan konstitusional, dan komite audit tidak berpengaruh secara signifikan terhadap manajemen laba.
\end{abstract}

Kata Kunci: konsentrasi kepemilikan, ukuran perusahaan, corporate governance, manajemen laba.

\section{JIAKES}


Banks' Earning

Management In

Indonesia

122

\section{PENDAHULUAN}

Teori keagenan menjelaskan tentang hubungan antara principal dan agent, principal bertindak sebagai kepala yang memberi wewenang dan agent bertindak sebagai yang menjalankan tugas yang diberikan oleh principal. Hubungan antara principal dan agent dapat bersifat asimetri information dikarenakan di dalam perusahaan agent memiliki informasi yang lebih banyak dibandingkan principal sehingga pihak agent dapat menyembunyikan informasi untuk kepentingan dirinya sendiri. Asimetri antara manajemen (agent) dan pemegang saham (principal) memberikan kesempatan kepada manajer untuk bertindak oportunis, yaitu memperoleh keuntungan pribadi. dalam hal pelaporan keuangan manajer dapat melakukan manajemen laba (earnings management) untuk menyesatkan pemilik (pemegang saham) mengenai kinerja ekonomi perusahaan.

Manajemen laba adalah suatu kondisi dimana manajemen melakukan intervensi dalam proses penyusunan laporan keuangan bagi pihak eksternal sehingga dapat meratakan, menaikkan, dan menurunkan laba (Schipper, 1989). Sedangkan Healy dan Wahlen (1999) menyatakan bahwa earnings management terjadi ketika manajemen menggunakan keputusan tertentu dalam pelaporan keuangan dan penyusunan transaksitransaksi yang mengubah laporan keuangan, hal ini bertujuan untuk menyesatkan para stakeholders tentang kondisi kinerja ekonomi perusahaan, serta untuk mempengaruhi penghasilan kontraktual yang mengendalikan angka akuntansi yang dilaporkan. Kasus manajemen laba banyak terjadi mulai dari skala nasional sampai dengan skala internasional. Contoh skandal besar berkaitan dengan manjemen laba tingkat internasional yang sangat terkenal adalah kasus Enron yaitu sebuah perusahaan energi di Amerika Serikat. Sebelum perusahaan itu jatuh, Enron tercatat memperkerjakan 21ribu karyawan lebih dari 40 negara bahkan harga sahamnya pernah mencapai US\$ 90 per-lembar saham. Untuk menarik mata investor Enron memanipulasi laporan keuangannya dengan menyembunyikan hutang sebesar $\$ 12$ billion (liputan 6,2014). Skandal ini tidak hanya membuat perusahaan mengalami kebangkrutan namun juga mengakibatkan para pelakunya diseret ke pengadilan sebagai pelaku kejahatan ekonomi.

Fenomena mengenai manajemen laba di Indonesia contoh kasusnya adalah pada PT Agis Tbk (Agis). Pada kasus ini Bapepam (badan pengawas pasar modal,2007) AGIS terbukti memberikan informasi yang secara material tidak besar terkait dengan pendapatan dari dua perusahaan yang diakuisisi yaitu PT Akira Indonesia dan PT TT Indonesia, dimana dinyatakan bahwa pendapatan kedua perusahaan tersebut adalah sebesar Rp. 800 miliar, namun demikian berdasarkan laporan keuangan kedua perusahaan yang akan diambil alih tersebut per 31 maret 2007 total pendapatannya hanya sebesar kurang lebih Rp 466,8 miliar. AGIS juga melakukan pelanggaran terkait laporan keuangan AGIS yang merupakan konsolidasi dari anak-anak perusahaan yang salah satunya adalah PT AGIS elektronik. Dalam laporan laba rugi konsolidasi AGIS diungkapkan pendapatan lain- lain bersih sebesar Rp 29,4 miliar yang berasal dari laporan keuangan AGIS elektronik sebagai anak perusahaan AGIS yang tidak didukung dengan bukti-bukti kompeten dan kesalahan prinsip akutansi. Dengan demikian pendapatan lain-lain dalam laporan keuangan AGIS elektronik tidak wajar yang berakibat laporan keuangan konsolidasi AGIS juga tidak wajar.

Kasus yang baru saja terjadi terkait manajemen laba di Indonesia yaitu terjadi pada PT Sunprima Nusantara Pembiyaan (SNP Finance). OJK membekukan kegiatan usaha SNP karena perseroan gagal membayar bunga MTN senilai Rp6,75 miliar pada 14 Mei 2018 melalui Surat Deputi Komisioner Pengawas IKNB II No. S-247/NB.2/2018. Hal ini disebabkan karena SNP Tidak menyampaikan laporan keuangan dengan benar alias fiktif. Praktik manajemen laba di perusahaan dapat menurunkan kualitas laporan keuangan perusahaan dan menurunkan citra perusahaan di mata stakeholders. Maka dari itu salah satu cara yang dapat dilakukan untuk memonitor masalah tersebut adalah dengan dengan menerapkan corporate governance di perusahaan. Corporate Governance merupakan cara untuk membawa kepentingan agen (manajer) dan prinsipal (investor) 
sejalan dan menjamin agar perusahaan dijalankan bagi kemanfaatan prinsipal (investor) (Mayer,1996).

Corporate governance merupakan konsep yang diajukan demi peningkatan kinerja perusahaan melalui supervisi atau monitoring kinerja manajemen dan menjamin akuntabilitas manajemen terhadap stakeholder dengan mendasarkan pada kerangka peraturan. Konsep corporate governance diajukan demi tercapainya pengelolaan perusahaan yang lebih transparan bagi semua pengguna laporan keuangan. Bila konsep ini diterapkan dengan baik maka diharapkan pertumbuhan ekonomi akan terus menanjak seiring dengan transparansi pengelolaan perusahaan yang makin baik dan nantinya akan menguntungkan banyak pihak (setiawan,2006). Dalam Corporate Governance, banyak hal yang di dapat dilakukan untuk membatasi perilaku opportunist manajemen antara lain membentuk dewan komisaris independen. Marihot dan Setiawan (2007) menyimpulkan bahwa proporsi dewan komisaris independen berpengaruh negatif terhadap manajemen laba. Artinya semakin banyak anggota dewan komisaris yang independen maka manajemen laba yang dilakukan agen akan semakin kecil. Namun, hasil penelitian Suryani (2010) manyimpulkan bahwa proporsi dewan komisaris independen tidak berpengaruh terhadap manajemen laba. Lalu dapat dilakukan dengan menganalisis ukuran dewan komisaris yang diukur secara tepat. Marihot dan Setiawan (2007) menyimpulkan bahwa ukuran dewan komisaris terhadap manajemen laba berpengaruh positif sedangkan menurut Arfan, dan Mabrurah (2017) menyimpulkan bahwa ukuran dewan komisaris berpengaruh negatif terhadap manajemen laba

Untuk memonitor kinerja manajemen melalui corporate governance dapat membentuk komite audit di suatu perusahaan. Chtourou (2001) Melakukan penelitian dengan menguji efektivitas komite audit terhadap manajemen laba, dari hasil penelitian tersebut diperoleh hasil positif berbeda dengan penelitian yang dilakukan oleh Apriliani dan Aloysius (2007) dimana komite audit tidak berpengaruh terhadap manajemen laba, Penilitian Veronica dan Utama (2005) menyimpulkan bahwa proporsi komisaris independen yang tinggi dan keberadaan komite audit tidak terbukti dapat membatasi pengelolaan laba yang dilakukan perusahaan sedangkan penelitian yang dilakukan oleh Marihot dan Setiawan (2007) menyimpulkan bahwa keberadaan komite audit memiliki pengaruh yang signifikan terhadap manajemen laba. Selain itu dapat dilakukan juga pengujian ukuran perusahaan terhadap manajemen laba. Penelitian Marihot dan Setiawan (2007) menyimpulkan bahwa ukuran perusahaan terhadap manajemen laba memiliki pengaruh negatif sama seperti hasil penelitian yang dilakukan oleh Veronica dan Utama (2005), artinya semakin besar ukuran perusahaan semakin kecil besaran pengelolaan labanya. Selain itu, rata-rata pengelolaan laba pada perusahaan dengan kepemilikan keluarga tinggi dan bukan perusahaan konglomerasi secara signifikan lebih tinggi daripada rata-rata pengelolaan laba pada perusahaan lain.

Auditor eksternal yang berkualitas diharapkan mampu membatasi perilaku opportunistic agent. Penelitian Welvin dan Herawaty (2008) menyimpulkan bahwa kualitas auditor berpengaruh positif terhadap manajemen laba. Namun, Meutia (2004) berargumen bahwa kualitas auditor berpengaruh negatif terhadap manajemen laba. Selain beberapa hal diatas, struktur kepemilikan konstitusional ternyata juga dapat membatasi praktik manajemen laba yang dilakukan oleh manajer. Cornet, Marcus, dan Tehranian (2007) menyatakan bahwa kepemilikan institusional berpengaruh negatif terhadap manajemen laba. Hermanto (2015) menyatakan bahwa kepemilikan institusional memiliki pengaruh signifikan terhadap manajemen laba dalam Pengaruh Kepemilikan Institusional, Ukuran perusahaan, Leverage terhadap manajemen laba. Hasil penelitian terdahulu tentang pengaruh mekanisme corporate governance terhadap manajemen laba ternyata menghasilkan kesimpulan yang tidak konsisten. Oleh karena itu, peneliti tertarik untuk melakukan penelitian ulang tentang pengaruh pengaruh corporate governance terhadap manajemen laba. Adapun penelitian ini bertujuan untuk:
Banks' Earning

Management in

Indonesia 
Banks' Earning

Management In

Indonesia

$\underline{124}$
1. menguji pengaruh ukuran perusahaan terhadap manajemen laba.

2. menguji pengaruh corporate governance yang terdiri dari ukurani dewan komisaris, keberadaan komite audit, kualitas auditor, kepemilikan konstitusional, dan proporsi dewan komisaris terhadap manajemen laba.

\section{METODE PENELITIAN}

Populasi yaitu sekelompok orang, kejadian, atau segala sesuatu yang mempunyai karakteristik tertentu. Sedangkan sampel merupakan sebagian dari elemen populasi (Indriantoro dan Supomo, 2002;115). Populasi dari penelitian ini adalah seluruh perusahaan perbankan yang terdaftar di Bursa Efek Indonesia. Metode pengambilan sampel yang digunakan dalam penelitian ini adalah metode judgement sampling dengan menggunakan teknik purposive sampling, yaitu dengan cara menunjukkan langsung pada suatu populasi berdasarkan karakteristik atau ciri yang dimiliki sampel, dengan tujuan agar diperoleh sampel yang representatif sesuai dengan kriteria yang ditentukan. Adapun kriteria pemilihan sampel adalah :

1. Emiten Perbankan yang mempublikasikan laporan keuangan tahunan untuk periode 31 Desember 2016-2018.

2. Laporan keuangan dalam mata uang Rupiah.

3. Data yang tersedia lengkap, baik data mengenai ukuran perusahaan ,dan corporate governance perusahaan dan data yang diperlukan untuk mendeteksi manajemen laba.

Manajemen laba sebagai variabel dependen penelitian ini merupakan setiap tindakan manajemen yang dapat mempengaruhi angka laba yang dilaporkan. Manajemen laba merupakan fenomena yang sukar dihindari karena fenomena ini merupakan dampak dari penggunaan dasar akrual dalam penyusunan laporan keuangan. Manajemen laba timbul sebagai dampak dari penggunaan akuntansi sebagai salah satu alat komunikasi antara pihak-pihak yang berkepentingan dan kelemahan inheren yang ada pada akuntansi yang menyebabkan adanya judgement (Setiawati, 2002). Dalam penelitian ini digunakan discretionary accruals (DAC) sebagai proksi manajemen laba yang dihitung dengan menggunakan Modified Jones Model. Dechow et al dalam Nuryaman (2008) menyatakan bahwa model modified Jones memiliki kemampuan yang lebih baik untuk mendeteksi manajemen laba dibandingkan model yang lain. Poin awal dalam pengukuran discretionary accruals adalah menghitung total akrual dimana dapat dibedakan menjadi dua bagian, yaitu discretionary accruals dan non discretionary accruals. Komponen discretionary accruals merupakan bagian dari akrual yang memungkinkan manajer melakukan intervensinya dalam memanipulasi laba perusahaan. Hal ini disebabkan karena manajer memiliki kemampuan untuk mengontrolnya dalam jangka pendek, discretionary accrual merupakan komponen akrual yang memungkinkan manajer untuk melakukan intervensi dalam proses penyusunan laporan keuangan, sehingga laba yang dilaporkan dalam laporan keuangan tidak mencerminkan nilai atau kondisi perusahaan yang sesunggguhnya, sehingga semakin besar discretionary accrual, maka semakin besar pula manajemen laba yang dilakukan oleh pihak manajemen.

Komponen discretionary accruals diantaranya terdiri dari penilaian piutang, pengakuan biaya garansi (future warranty expense) dan asset modal (capitalization assets). Sedangkan komponen non-discretionary accruals ditentukan oleh faktor-faktor lain yang tidak dapat diawasi oleh manajer. Total akrual diklasifikasikan menjadi komponen discretionary dan nondiscretionary (Midiastuty, 2003), dengan tahapan:

a. Mengukur total accrual dengan menggunakan model Jones yang dimodifikasi. Total Accrual $(\mathrm{TAC})=$ laba bersih setelah pajak (net income) - arus kas operasi (cash flow from operating)

b. Menghitung nilai accruals yang diestimasi dengan persamaan regresi OLS (Ordinary Least Square): 


\section{$T A C_{t}$ : total accruals perusahaan i pada periode $\mathrm{t}$}

Dimana :

$T A C_{t} / A_{t-1}=\alpha_{1}\left(1-A_{t-1}\right)+\alpha_{2}\left(\left(\Delta R E V_{t}-\Delta R E C_{t}\right) / A_{t-1}\right)+\alpha_{3}$ $\left(P P E_{t} / A_{t-1}\right)+\mathrm{e}$

Banks' Earning

Management in

Indonesia

$A_{t-1}$ : total aset untuk sampel perusahaan i pada akhit tahun t-1

$R E V_{t}$ : perubahan pendapatan perusahaan i dari tahun $\mathrm{t}-1$ ke tahun $\mathrm{t}$

$R E C_{t}$ : perubahan piutang perusahaan i dari tahun $\mathrm{t}-1$ ke tahun $\mathrm{t}$

$P P E_{t}$ :aktiva tetap (gross property plant and equipment) perusahaan tahun $\mathrm{t}$

c. Menghitung nondiscretionary accruals model (NDA) adalah sebagai berikut :

$N D A_{t}=\beta_{1}\left(1 / A_{t-1}\right)+\beta_{2}\left(\left(\Delta R E V_{t}-\Delta R E C_{t}\right) / A_{t-1}\right)+\beta_{3}\left(P P E_{t} / A_{t-1}\right)+\mathrm{e}$

NDAt : nondiscretionary accruals pada tahun $\mathrm{t}$

$\beta \quad$ : fitted coefficient yang diperoleh dari hasil regresi pada perhitungan total accruals

d. Menghitung discretionary accruals

\section{Dimana :}

$D A C_{t}:\left(T A C_{t} / A_{t-1}\right)-N D A_{t}$

$D A C_{t} \quad$ : discretionary accruals perusahaan i pada periode $\mathrm{t}$

Variabel independen yang digunakan dalam penelitian ini yaitu ukuran perusahaan dan mekanisme corporate governance dengan proksi ukuran dewan komisaris, keberadaan komite audit, kualitas auditor, kepemilikan konstitusional, dan proporsi dewan komisaris. Ukuran perusahaan (SIZE) adalah besar kecilnya perusahaan. Pada penelitian ini ukuran perusahaan menggunakan nilai log total aset perusahaan pada akhir tahun. Ukuran Dewan Komisaris digambarkan oleh Komposisi dewan komisaris (BOD) adalah susunan keanggotaan yang terdiri dari komisaris dari luar perusahaan (outside director) dan komisaris dari dalam perusahaan (inside director). Variabel ini dihitung dengan cara menghitung nilai log total seluruh anggota dewan komisaris di suatu perusahaan. Keberadaan komite audit (AC) sekurang-kurangnya terdiri dari 3 anggota, seorang diantaranya komisaris independen perusahaan tercatat sekaligus menjadi ketua komite, sedangkan yang lain adalah pihak ekstern yang independen dan minimal salah seorang memiliki kemampuan di bidang akuntansi dan keuangan. Komposisi komite audit diukur dengan menggunakan indikator persentase anggota komite audit dari luar terhadap seluruh anggota komite audit. Kualitas Auditor diukur dengan Spesialisasi Industri KAP (AUDIT) yang menggambarkan keahlian dan pengalaman audit seorang auditor pada bidang industri tertentu. Auditor tersebut memiliki memiliki pengetahuan yang spesifik dan mendalam serta berpengalaman dalam suatu bidang industri tertentu (Almutari, 2007). Auditor industri spesialis diyakini mampu mendeteksi kesalahan-kesalahan secara lebih baik, meningkatkan efisiensi dan meningkatkan penilaian tentang kejujuran laporan keuangan. Spesialisasi industri auditor diproksi dengan konsentrasi jasa audit auditor pada bidang tertentu. Spesialisasi Industri KAP pada penelitian ini adalah auditor yang memiliki volume klien minimal $15 \%$ dari jumlah klien pada kelompok industri tertentu (Mayangsari, 2003). Pengukuran variabel ini menggunakan variabel dummy, nilai 1 jika perusahaan diaudit oleh auditor spesialis, dan 0 jika lainnya.

Kepemilikan institusional merupakan kepemilikan saham perusahaan oleh institusi keuangan seperti perusahaan asuransi, bank, dana pensiun, dan investment banking (Veronica dan Utama 2005). Kepemilikan institusional diukur dengan skala rasio melalui jumlah saham yang dimiliki oleh investor institusional dibandingkan dengan total saham perusahaan.

INST $=($ Jumlah saham yang dimiliki investor institusi $) /($ Total modal saham perusahaan yang beredar) $\mathrm{x} 100 \%$

Proporsi dewan komisaris independen adalah anggota dewan komisaris yang tidak terafiliasi dengan manajemen, anggota dewan komisaris lainnya, pemegang saham pengendali, dan bebas dari hubungan bisnis atau hubungan lainnya yang dapat mempengaruhi kemampuannya untuk bertindak sematamata demi kepentingan 
Banks'Earning

Management In

Indonesia

126 perusahaan (Boediono, 2005). Proporsi dewan komisaris independen diukur dari jumlah persentase dewan komisaris independen terhadap jumlah total komisaris yang ada dalam susunan dewan komisaris perusahaan sampel atau dengan rumus (Antonia, 2008): Proporsi dew. komisaris independen $=$ (jumlah dewan komisaris indpenden )/(total anggotan dewan komisaris) x 100\%. Pengumpulan data dalam penelitian ini dengan mengambil data sekunder, maka metode pengumpulan data yang digunakan adalah metode purposive sampling. Dengan metode tersebut sampel dipilih atas dasar kesesuaian karakteristik sampel dengan kriteria pemilihan sampel yang ditentukan. Data penelitian dianalisis menggunakan Analisis Statistik Deskriptif, Uji asumsi klasik nalisis Regresi Linier Berganda, Uji Koefisien Determinasi (R2), Uji Signifikansi Simultan (Uji Statistik F) dan Uji Signifikansi Parameter Individual (Uji Statistik t)

\section{HASIL DAN PEMBAHASAN}

\section{Deskripsi Objek dan Penelitian}

Penelitian ini menggunakan sampel perusahaan perbankan yang terdaftar di Bursa Efek Indonesia (BEI) mulai tahun 2016-2018 yang dipilih dengan purposive sampling method. Berdasarkan kriteria yang telah ditetapkan pada bab III diperoleh jumlah sampel sebanyak 41 perusahaan yang terdaftar di Bursa Efek Indonesia (BEI) periode 2016-2018 dengan data observasi sebanyak 123. Ringkasan prosedur pemilihan sampel dapat dilihat pada tabel 1 .

Tabel 1 Prosedur Pemilihan Sample

\begin{tabular}{|l|l|}
\hline \multicolumn{1}{|c|}{ Keterangan } & Jumlah Perusahaan \\
\hline Populasi Perusahaan Perbankan & 45 \\
\hline Perusahaan yang tidak menerbitkan laporan keuangan & $(1)$ \\
\hline $\begin{array}{l}\text { Data mengenai variable independen \& independen tidak } \\
\text { lengkap }\end{array}$ & $(3)$ \\
\hline Perusahaan yang terpilih menjadi sample & 41 \\
\hline $\begin{array}{l}\text { Periode 2016-2018 } \\
\text { 42 Perusahaan x 3 Tahun }\end{array}$ & Jumlah Observasi \\
\hline
\end{tabular}

Dari keseluruhan jumlah perusahaan perbankan yang ada di BEI periode 2016-2018, terdapat 41 perusahaan yang memenuhi kriteria yang telah ditetapkan dalampemilihan sampel.

\section{Analisis Statistik Deskriptif}

Dalam penelitian ini diambil data laporan keuangan pada tahun 2016 sampai dengan 2018 dengan sampel sebanyak 41 perusahaan perbankan, maka secara pooled cross sectional diperoleh sejumlah 41 perusahaan $\times 3$ tahun $=123$ data observasi.

Tabel 2 Statistik Deskriptif

\begin{tabular}{|c|c|c|c|c|c|}
\hline & $\mathrm{N}$ & Minimum & Maximum & Mean & Std. Deviation \\
\hline Manajemen Laba & 123 & -.29 & .381 & .00992 & .13932 \\
\hline Ukuran Perusahaan & 123 & 28.353 & 34.799 & 31.152 & 1.7826 \\
\hline Ukuran Dewan Komisaris & 123 & 2.000 & 9.000 & 5.000 & 1.9077 \\
\hline Keberadaan Komite Audit & 123 & .167 & .429 & .29865 & .052926 \\
\hline Kualitas Auditor & 123 & .000 & 1.000 & .70732 & .45685 \\
\hline Kepemilikan Konstitusional & 123 & .118 & .984 & .66623 & .22244 \\
\hline Proporsi Dewan Komisaris & 123 & 20.000 & 80.000 & 52.674 & 12.879 \\
\hline Valid N (listwise) & 123 & & & & \\
\hline
\end{tabular}

Sumber : Data sekunder yang diolah 2020

Variabel independen yang digunakan dalam penelitian ini adalah ukuran perusahaan, ukuran dewan komisaris, keberadaan komite audit, kualitas auditor, kepemilikan institusional, dan proporsi dewan komisaris, sedangkan variabel dependennya adalah manajemen laba. Data variabel diperoleh melalui perhitungan yang diolah berdasarkan laporan keuangan tahunan yang diperoleh dari BEI. Analisis 
statistik deskriptif akan memberikan gambaran atau deskripsi suatu data yang dilihat dari nilai minimum, maksimum, rata-rata (mean), dan standar deviasi yang dihasilkan dari variabel penelitian. Hasil analisis dengan statistik deskriptif menghasilkan data sebagaimana tabel 2. Berdasarkan Tabel 2 dari 41 perusahaan yang menjadi sample, didapatkan nilai minimum independensi ukuran perusahaan sebesar 28,35 dan nilai maksimum sebesar 34,79 atau dalam presentase berarti berada di $28 \%$ dan $34 \%$. Nilai standar deviasi sebesar 1,78 dan nilai rata-rata (mean) untuk variabel independensi ukuran perusahaan sebesar 31,15 artinya data kurang bervariasi karena nilai standar deviasinya lebih kecil dari pada mean.

Berdasarkan hasil analisis diketahui bahwa nilai minimum ukuran dewan komisaris sebesar 2,00 yang menunjukkan bahwa nilai terendah rasio dewan komisaris independen terhadap total jumlah dewan komisaris sebesar 2 orang. Nilai maksimal sebesar 9,00 menunjukkan bahwa nilai tertinggi rasio jumlah anggota dewan komisaris independen terhadap total jumlah anggota dewan komisaris adalah sebesar 9 orang. Nilai mean sebesar 5 menunjukkan bahwa rata-rata rasio anggota dewan komisaris independen terhadap total jumlah anggota dewan komisaris adalah sebanyak 5 orang. Sedangkan nilai standar deviasi sebesar 1,90 atau lebih kecil dari nilai rata-ratanya, sehingga menunjukkan bahwa data penelitian dari ukuran dewan komisaris kurang bervariasi. Nilai minimum variabel komite audit menunjukkan nilai minimum sebesar 0 dan nilai maksimum sebesar 1 dengan nilai rata-rata sebesar 0,70 sedangkan standar deviasinya sebesar 0,456 atau lebih kecil dari nilai rata-ratanya, sehingga menunjukkan bahwa data penelitian dari ukuran dewan komisaris kurang bervariasi.

Pada variabel kepemilikan institusional nilai minimumnya adalah 0,11 , nilai maksimum 0,98, mean 0,66, dan standar deviasi 0,22. Artinya, kepemilikan institusional yang dimiliki oleh perusahaan sampel paling kecil $11 \%$, paling besar $98 \%$, rata-rata kepemilikan institusional yang dimiliki perusahaan sampel adalah $66 \%$. Standar deviasi yang menunjukkan variasi yang terdapat dalam kepemilikan institusional adalah $11 \%$ atau lebih kecil dari nilai rata-ratanya, sehingga menunjukkan bahwa data penelitian dari kepemilikan institusional kurang bervariasi. Berdasarkan hasil analisis diketahui bahwa nilai minimum proporsi dewan komisaris independen sebesar 20 yang menunjukkan bahwa nilai terendah proporsi dewan komisaris independen terhadap total jumlah dewan komisaris sebesar $20 \%$. Nilai maksimal sebesar 80 menunjukkan bahwa nilai tertinggi rasio jumlah anggota dewan komisaris independen terhadap total jumlah anggota dewan komisaris adalah sebesar 80\%. Nilai mean sebesar 52,67 menunjukkan bahwa rata-rata rasio anggota dewan komisaris independen terhadap total jumlah anggota dewan komisaris adalah sebesar 52,67\%. Sedangkan nilai standar deviasi sebesar 12,87, atau lebih kecil dari nilai rata-ratanya, sehingga menunjukkan bahwa data penelitian dari proporsi dewan komisaris independen kurang bervariasi. Secara umum disimpulkan bahwa rata-rata emiten telah memenuhi ketentuan Peraturan Pencatatan Nomor IA tentang Ketentuan Umum Pencatatan Efek bersifat Ekuitas di Bursa yang menyatakan bahwa jumlah dewan komisaris independen minimum adalah sebesar 30\% dilihat dari mean yang dihasilkan sebesar 52,87\%, bahkan ada perusahaan yang membentuk dewan komisaris independen sebesar $80 \%$ atau $80 \%$ dari seluruh dewan komisaris terdiri dari dewan komisaris independen. Namun, masih ada juga perusahaan yang belum memenuhi peraturan BAPEPAM dilihat dari nilai minimum yaitu sebesar $20 \%$.

Tabel 3 Frekuensi Kualitas Auditor

\begin{tabular}{|c|c|c|}
\hline \multirow{2}{*}{ Keterangan } & Proporsi & Proporsi \\
\cline { 2 - 3 } & Dummy $=1$ & Dummy $=0$ \\
\hline Kualitas Auditor & $70,73 \%$ & $29,27 \%$ \\
\hline
\end{tabular}

Sumber: Data sekunder yang diolah, 2020

Berdasarkan hasil analisis diketahui bahwa perusahaan yang menggunakan jasa audit auditor big four lebih dominan dibandingkan dengan perusahaan yang menggunakan auditor non big four, atau sebesar 70,73\%. Hal ini menunjukkan bahwa

Banks' Earning Management in Indonesia 
Banks' Earning Management In Indonesia

128 perusahaan yang masuk dalam kelompok big four lebih banyak digunakan, karena dianggap memiliki reputasi yang lebih baik dibandingkan dengan auditor yang tidak masuk dalam kelompok big four.

\section{Uji Asumsi Klasik}

Uji Asumsi Klasik digunakan untuk menguji, apakah model regresi yang digunakan dalam penelitian ini layak untuk diuji atau tidak. Persamaan tersebut harus dapat diterima secara ekonometrik maka harus memenuhi asumsi klasik, antara lain dengan menggunakan Uji Normalitas, Multikolinearitas, Autokorelasi, dan Heteroskedastisitas. Jika keseluruhan syarat tersebut terpenuhi, berarti model analisis telah layak digunakan.

Uji normalitas bertujuan untuk menguji apakah dalam model regresi, variabel dependen dan variabel independen berdistribusi normal atau berdistribusi tidak normal. Model regresi yang baik adalah distribusi data normal atau mendekati normal. Untuk menguji normalitas data, pada penelitian ini menggunakan metode uji statistik nonparametrik Kolmogorov-Smirnov. Menurut Imam Ghozali (2005), bahwa distribusi data dapat dilihat dengan membandingkan $\mathrm{Z}$ hitung dengan tabel $\mathrm{Z}$ tabel dengan kriteria sebagai berikut:

- Data berdistribusi normal, jika nilai sig (signifikansi) $>0.05$.

- Data berdistribusi tidak normal, jika nilai sig (signifikansi) $<0.05$.

Hasil uji normalitas tersebut dapat diketahui dari nilai Unstandardized Residual pada Tabel 4 berikut:

Tabel 4 Hasil Uji Normalitas dengan Kolmogorov Smirnov

\begin{tabular}{|c|c|c|}
\hline & & $\begin{array}{c}\text { Unstandardized } \\
\text { Residual }\end{array}$ \\
\hline $\mathrm{N}$ & & 123 \\
\hline Normal & Mean & .0000000 \\
\hline Parameters ${ }^{\mathrm{a}, \mathrm{b}}$ & Std. Deviation & .12308211 \\
\hline Most Extreme & Absolute & .077 \\
\hline Differences & Positive & .077 \\
\hline & Negative & -.049 \\
\hline Test Statistic & & .077 \\
\hline Asymp. Sig. (2-tai & & $.072^{\mathrm{c}}$ \\
\hline Monte Carlo Sig. & Sig. & $.447^{\mathrm{d}}$ \\
\hline (2-tailed) & $99 \%$ Confidence Interval Lower Bound & .434 \\
\hline & Upper Bound & .460 \\
\hline
\end{tabular}

Sumber: Data sekunder yang diolah, 2020

Tabel 5 Hasil Uji Multikoloniaritas

\begin{tabular}{|c|l|l|l|l|}
\hline \multirow{2}{*}{\multicolumn{2}{|c|}{ Model }} & \multicolumn{2}{c|}{ Collinearity } & \multirow{2}{*}{ Keterangan } \\
\cline { 3 - 4 } \multicolumn{2}{|c|}{} & Tolerance & VIF & \\
\hline 1 & (Constant) & & & \\
\hline & Ukuran Perusahaan & 0.733 & 1.364 & Tidak terjadi multikolinearitas \\
\hline & Ukuran Dewan Komisaris & 0.959 & 1.043 & Tidak terjadi multikolinearitas \\
\hline & Keberadaan Komite Audit & 0.967 & 1.038 & Tidak terjadi multikolinearitas \\
\hline & Kualitas Auditor & 0.735 & 1.367 & Tidak terjadi multikolinearitas \\
\hline & Kepemilikan Konstitusional & 0.957 & 1.045 & Tidak terjadi multikolinearitas \\
\hline & Proporsi Dewan Komisaris & 0.973 & 1.028 & Tidak terjadi multikolinearitas \\
\hline
\end{tabular}

Sumber: Data sekunder yang diolah, 2020

Hasil pengujian normalitas dengan uji statistik non-parametrik KolmogorovSmirnov menunjukkan bahwa besarnya nilai Kolmogorov-Smirnov adalah 0,447 dan tidak signifikan pada 0,447 . (karena $p=0,447>0,05$ ) yang berarti bahwa residual terdistribusi secara normal. Uji multikoloniaritas bertujuan untuk menguji apakah dalam model regresi ditemukan adanya korelasi antar variabel bebas. Model regresi 
yang baik seharusnya tidak terjadi korelasi antara variabel bebas. Multikoloniaritas dapat dilihat dari nilai tolerance dan variance inflation factor (VIF). Batas dari nilai VIF adalah 10 dan tolerance value adalah 0,1 . Jika nilai VIF lebih besar dari 10 dan nilai tolerance kurang dari 0,1 maka akan terjadi multikoloniaritas dan model regresi tidak layak untuk dipakai. Hasil perhitungan nilai tolerance serta VIF dapat diketahui pada Tabel 5. Memperhatikan hasil perhitungan dalam tabel diatas tampak bahwa nilai tolerance dari setiap variabel independent di atas 0,1 . Hal ini menunjukkan tidak ada variabel independen yang memiliki nilai tolerance kurang dari 0,1 dan nilai variance inflation factor (VIF) dari setiap variabel independen di bawah 10. Hal ini menunjukkan bahwa tidak ada variabel independen yang memiliki nilai VIF lebih dari 10, dengan demikian dapat disimpulkan bahwa tidak ada multikolonieritas antara variabel independen dalam model regresi.

Uji Heteroskedastisitas bertujuan untuk menguji apakah dalam model regresi terjadi ketidaksamaan variance dari residual satu pengamatan ke pengamatan yang lain. Jika variance dari residual satu pengamatan ke pengamatan lain tetap, maka disebut homoskedastisitas dan jika berbeda disebut heteroskedastisitas. Model regresi yang baik adalah yang homoskedastisitas atau tidak terjadi heteroskedastisitas (Ghozali, 2006). Pada penelitian ini digunakan uji Glejser untuk mendeteksi ada atau tidaknya heteroskedastisitas. Hasil uji Heteroskedastisitas dengan menggunakan uji Glejser adalah sebagai berikut:

\section{Tabel 6 Hasil Uji Glejser}

\begin{tabular}{|c|c|c|c|c|c|c|}
\hline \multirow{2}{*}{\multicolumn{2}{|c|}{ Model }} & \multicolumn{2}{|c|}{$\begin{array}{l}\text { Unstandardized } \\
\text { Coefficients }\end{array}$} & \multirow{2}{*}{$\begin{array}{c}\text { Standardized } \\
\text { Coefficients } \\
\text { Beta }\end{array}$} & \multirow[t]{2}{*}{$\mathrm{t}$} & \multirow[t]{2}{*}{ Sig. } \\
\hline & & $\mathrm{B}$ & Std. Error & & & \\
\hline \multirow{7}{*}{1} & (Constant) & .046 & .142 & & .300 & .765 \\
\hline & Ukuran Perusahaan & .003 & .004 & .070 & .515 & .515 \\
\hline & Ukuran Dewan Komisaris & .000 & .003 & -.010 & -1.102 & .919 \\
\hline & Keberadaan Komite Audit & -.103 & .123 & -.079 & -.836 & .405 \\
\hline & Kualitas Auditor & -.011 & .016 & -.072 & -.671 & .503 \\
\hline & $\begin{array}{c}\text { Kepemilikan } \\
\text { Konstitusional }\end{array}$ & .023 & .029 & .072 & .766 & .445 \\
\hline & Proporsi Dewan Komisaris & $-2.092 \mathrm{E}-5$ & .001 & -.004 & -.042 & .967 \\
\hline
\end{tabular}

a. Dependent Variable: ABRESID

Sumber: Data sekunder yang diolah, 2020

Dari hasil diatas dapat diketahui bahwa model regresi bebas dari masalah Heteroskedastisitas. Hal ini terlihat dari nilai signifikansi variabel independen (Ukuran Perusahaan, Ukuran Dewan Komisaris, Keberadaan Komite Audit, Kualitas Auditor, Kepemilikan Konstitusional, Proporsi Dewan Komisaris) lebih besar dari tingkat signifikansi sebesar 0,05 .

Uji autokorelasi bertujuan untuk menguji apakah dalam suatu model regresi linier ada korelasi antar anggota sampel yang diurutkan berdasarkan waktu. Penyimpangan asumsi ini biasanya muncul pada observasi yang menggunakan time series. Untuk mendiaknosis adanya autokorelasi dalam suatu model regresi dilakukan melalui pengujian terhadap nilai Durbin-Watson. Output uji autokorelasi dapat dilihat pada tabel berikut ini:

Tabel 7 Hasil Uji Autokorelasi dengan Durbin-Watson

\begin{tabular}{|l|l|}
\hline \multicolumn{2}{|c|}{ Model Summaryb } \\
\hline Model & Durbin-Watson \\
\hline 1 & 2,101 \\
\hline
\end{tabular}

Sumber: Data sekunder yang diolah, 2020
Banks' Earning Management in Indonesia

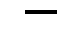


Banks' Earning

Management In

Indonesia

130

Dari pengujian statistik diperoleh nilai Durbin-Watson sebesar 2,101 $(\mathrm{du}=1,807 ; 4$ - du 2,192). Nilai D-W statistik berada di daerah bebas autokorelasi, hal ini berarti dapat disimpulkan bahwa tidak terdapat autokorelasi dalam model regresi, jadi model regresi di atas tidak terdapat masalah autokorelasi, oleh karena itu model regresi ini dinyatakan layak untuk dipakai.

\section{Analisis Regresi Linier Berganda}

Analisis regresi linier berganda digunakan untuk menguji hipotesis tentang pengaruh variabel independen secara simultan maupun parsial. Hasil analisis regresi dapat dilihat pada Tabel 8 berikut ini:

Tabel 8 Hasil Analisis Regresi

\begin{tabular}{|c|c|c|c|}
\hline \multirow{2}{*}{\multicolumn{2}{|c|}{ Model }} & \multicolumn{2}{|c|}{ Unstandardized Coefficients } \\
\hline & & $\mathrm{B}$ & Std. Error \\
\hline \multirow[t]{7}{*}{1} & (Constant) & .591 & 253 \\
\hline & Ukuran Perusahaan (X1) & -.018 & .007 \\
\hline & Ukuran Dewan Komisaris (X2) & -.016 & .006 \\
\hline & Keberadaan Komite Audit (X3) & .143 & .220 \\
\hline & Kualitas Auditor (X4) & .011 & .029 \\
\hline & Kepemilikan Konstitusional (X5) & .087 & .053 \\
\hline & Proporsi Dewan Komisaris (X6) & -.003 & .001 \\
\hline
\end{tabular}

Sumber: Data sekunder yang diolah, 2020

Dari tabel di atas maka dibuat persamaan regresi sebagai berikut:

$\mathrm{DA}=0,591-0,018 \mathrm{X} 1-0,016 \mathrm{X} 2+0,143 \mathrm{X} 3+0,011 \mathrm{X} 4+0,087 \mathrm{X} 5-0.003 \mathrm{X} 6$

Dari hasil diatas dapat diketahui bahwa variabel ukuran perusahaan (X1), ukuran dewan domisaris (X2), keberadaan komite Audit (X3), kualitas auditor (X4) dan kepemilikan konstitusional (X5) memiliki pengaruh ke arah positif terhadap manajemen laba sedangkan variabel proporsi dewan komisaris (X6) memiliki pengaruh ke arah negatif terhadap manajemen laba. Adapun interpretasi atas persamaan regresi tersebut dapat dinyatakan sebagai berikut:

1. Koefisien regresi ukuran perusahaan (X1) sebesar -0,018

menyatakan bahwa setiap perubahan ukuran perusahaan sebesar $1 \%$ maka manajemen laba akan cenderung turun sebesar $-0,018(-1,8 \%)$ dengan anggapan bahwa variabel lain, yaitu ukuran dewan komisaris (X2), keberadaan komite audit (X3), kualitas auditor (X4), kepemilikan institusional (X5), dan proporsi dewan komisaris (X6). Adanya hubungan yang negatif ini, berarti bahwa antara ukuran perusahaan dengan manajemen laba menunjukkan hubungan yang berlawanan, artinya setiap kenaikan ukuran perusahaan akan cenderung diikuti oleh penurunan manajemen laba dan sebaliknya penurunan ukuran perusahaan cenderung mengakibatkan kenaikan manajemen laba.

2. Koefisien regresi ukuran dewan komisaris (X2) sebesar -0,016 menyatakan bahwa setiap perubahan ukuran dewan komisaris sebesar $1 \%$ maka manajemen laba akan cenderung turun sebesar $-0,016(-1,6 \%)$ dengan anggapan bahwa variabel lain, yaitu ukuran perusahaan (X1), keberadaan komite audit (X3), kualitas auditor (X4), kepemilikan institusional (X5), dan proporsi dewan komisaris (X6). Adanya hubungan yang negatif ini, berarti bahwa antara ukuran dewan komisaris dengan manajemen laba menunjukkan hubungan yang berlawanan, artinya setiap kenaikan ukuran dewan komisaris akan cenderung diikuti oleh penurunan manajemen laba dan sebaliknya penurunan ukuran dewan komisaris cenderung mengakibatkan kenaikkan manajemen laba.

3. Koefisien regresi keberadaan komite audit (X3) sebesar 0,143 menyatakan bahwa setiap perubahan ukuran dewan komisaris sebesar $1 \%$ maka manajemen laba akan cenderung naik sebesar 0,143 (14,3\%) dengan anggapan bahwa variable lain, yaitu ukuran perusahaan (X1), keberadaan komite audit (X3), kualitas auditor (X4), kepemilikan institusional (X5), dan proporsi dewan komisaris (X6). Adanya hubungan yang positif ini, berarti bahwa antara keberadaan komite audit dengan 
manajemen laba menunjukkan hubungan yang searah, artinya setiap kenaikan komite audit akan cenderung diikuti oleh kenaikan manajemen laba, dan penurunan manajemen laba cenderung mengakibatkan penurunan komite audit.

4. Koefisien regresi kualitas auditor (X4) sebesar 0,011 menyatakan bahwa setiap perubahan kusliitas auditor sebesar 1 maka manajemen laba akan cenderung naik sebesar $0,011(1,1 \%)$ dengan anggapan bahwa variable lain, yaitu ukuran perusahaan (X1), keberadaan komite audit (X3), kualitas auditor (X4), kepemilikan institusional (X5), dan proporsi dewan komisaris (X6). Adanya hubungan yang positif ini, berarti bahwa antara kualitas auditor dengan manajemen laba menunjukkan hubungan yang searah, artinya setiap kenaikan kualitas auditor akan cenderung diikuti oleh kenaikan manajemen laba dan penurunan kualitas auditor cenderung mengakibatkan penurunan manajemen laba.

5. Koefisien regresi kepemilikan konstitusional (X5) sebesar 0,087 menyatakan bahwa setiap perubahan kepemilikan konstitusional sebesar 1 maka manajemen laba akan cenderung naik sebesar $0,087(8,7 \%)$ dengan anggapan bahwa variable lain, yaitu proporsi dewan komisaris independen (X1), keberadaan komite audit (X3), kualitas auditor (X4), kepemilikan institusional (X5), dan proporsi dewan komisaris (X6). Adanya hubungan yang poaitif ini, berarti bahwa antara kepemilikan konstitusional dengan manajemen laba menunjukkan hubungan yang searah, artinya setiap kenaikan kepemilikan institusional akan cenderung diikuti oleh kenaikan manajemen laba dan penurunan kepemilikan institusional cenderung mengakibatkan penurunan manajemen laba.

6. Koefisien regresi proporsi dewan komisaris (X6) sebesar - 0,003 menyatakan bahwa setiap perubahan proporsi dewan komisaris sebesar $1 \%$ maka manajemen laba akan cenderung menurun sebesar $-0,003(-0,3 \%)$ dengan anggapan bahwa variabel lain, yaitu proporsi dewan komisaris independen (X1), ukuran dewan komisaris (X2), keberadaan komite audit (X3), kepemilikan institusional (X5), dan kepemilikan manajerial (X6). Adanya hubungan yang negatif ini, berarti bahwa antara proporsi dewan komisaris dengan manajemen laba menunjukkan hubungan yang berlawanan, artinya setiap kenaikan proporsi dewan komisaris akan cenderung diikuti oleh penurunan manajemen laba dan sebaliknya penurunan proporsi dewan komisaris cenderung mengakibatkan kenaikan manajemen laba.

\section{Uji Koefisien Determinasi $\left(\mathbf{R}^{2}\right)$}

Uji koefisien determinasi digunakan untuk mengukur seberapa jauh kemampuan model dalam menerangkan variasi variabel independen terhadap variabel dependen. Hasil dari koefisien determinasi dapat dilihat pada Tabel 9 di bawah ini:

\section{Tabel 9 Hasil Uji Koefisien Determinasi}

\begin{tabular}{|c|c|c|c|c|}
\hline \multicolumn{5}{|c|}{ Model Summaryb } \\
\hline Model & $\mathrm{R}$ & R Square & Adjusted R Square & Std. Error of the Estimate \\
\hline 1 & $.415 \mathrm{a}$ & 0.172 & 0.129 & 0.12377 \\
\hline
\end{tabular}

Sumber: Data sekunder yang diolah, 2020

Dari Tabel 9 diatas dapat diketahui bahwa Adjusted $R$ Square $\left(\mathrm{R}^{2}\right)$ adalah 0,179 . Hal ini berarti bahwa $12,9 \%$ variabel manajemen laba (discretionary accruals) dapat dijelaskan oleh variabel independen yaitu proporsi dewan komisaris independen (X1), ukuran dewan komisaris (X2), keberadaan komite audit (X3), kepemilikan institusional (X5), dan proporsi dewan komisaris (X6) Sedangkan sisanya sebesar 87,1\% dijelaskan oleh faktor-faktor lain diluar model yang dianalisis.

Tabel 10 Hasil Uji Simultan (Uji F)

\begin{tabular}{|l|l|l|l|l|l|l|}
\hline Model & & Sum of Squares & df & Mean Square & F & Sig. \\
\hline 1 & Regression & 0.52 & 6 & 0.087 & 5.439 & .000 \\
\hline & Residual & 1.848 & 116 & 0.016 & & \\
\hline & Total & 2.368 & 122 & & & \\
\hline
\end{tabular}

Sumber: Data sekunder yang diolah, 2020
Banks' Earning

Management in

Indonesia 
Banks' Earning

Management In

Indonesia

132

\section{Uji Signifikansi Simultan (Uji Statistik F)}

Uji pengaruh simultan digunakan untuk mengetahui apakah variabel independen secara bersama-sama atau simultan mempengaruhi variabel dependen. Hasil uji $\mathrm{F}$ dalam penelitian dapat dilihat pada tabel 10. Dari Tabel 10 di atas dapat diketahui bahwa model persamaan ini memiliki tingkat signifikansi, yaitu 0,000 lebih kecil dibandingkan taraf signifikansi $\alpha(0,05)$, maka dapat disimpulkan bahwa variabel independen dalam model penelitian ini secara simultan dapat berpengaruh terhadap variabel dependen yaitu manajemen laba (discretionary accruals).

\section{Uji Signifikansi Parameter Individual (Uji Statistik t)}

Untuk menguji hipotesis maka analisis statistik yang digunakan dalam penelitian ini yaitu regresi linier berganda. Analisis ini digunakan untuk mengetahui besarnya pengaruh variabel independen yaitu ukuran perusahaan dan mekanisme corporate governance terhadap variabel dependen yaitu manajemen laba.

Tabel 11 Hasil Uji Hipotesis Parsial t

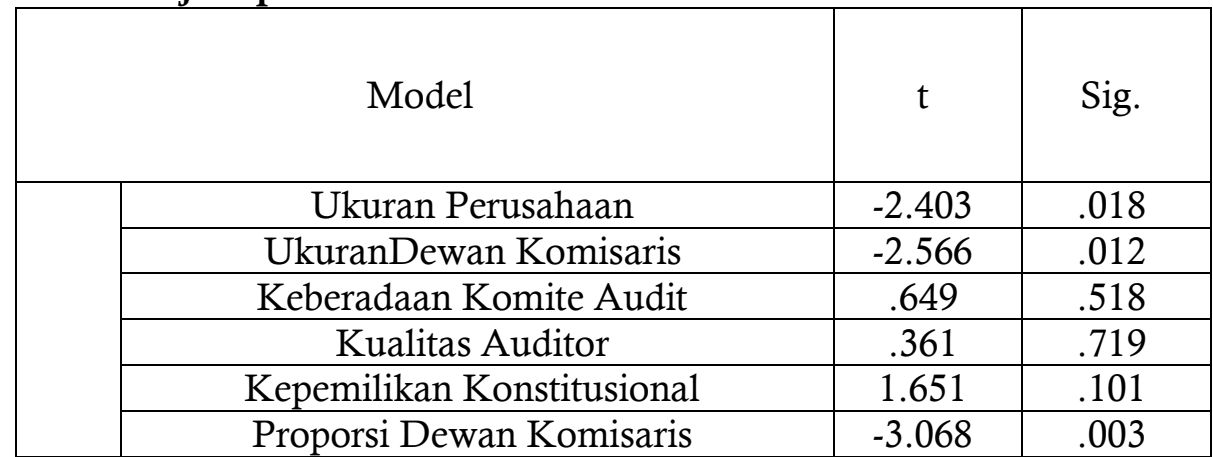

Sumber: Data sekunder yang diolah, 2020

Berdasarkan hasil uji statistik $t$ menunjukkan bahwa dari 5 variabel yang dimasukkan dalam model regresi, hanya variabel ukuran perusahaan, ukuran dewan komisaris, dan proporsi dewan komisaris yang signifikan mempengaruhi manajemen laba . Hal ini dapat dilihat dari nilai probabilitas signifikansi untuk ukuran perusahaan sebesar 0,018 ( $p<0,05)$, ukuran dewan komisaris 0,012 ( $p<0,05)$, dan untuk proporsi dewan komisaris $0,003(p<0,05)$. Sedangkan variabel komposisi keberadaan komite audit, kualitas auditor, dan kepemilikan konstitusional ditemukan tidak signifikan. Hal ini terlihat dari nilai probabilitas signifikansi secara berurutan sebesar 0,518 $(p>0,05)$, $0,719$ ( $p>0,05)$, dan $0,101(p>0,05)$. Jadi dapat disimpulkan bahwa variabel manajemen laba hanya dipengaruhi oleh variabel konsentrasi kepemilikan, ukuran perusahaan, ukuran dewan komisaris dan kualitas auditor.

\section{Hasil Pengujian Hipotesis}

Penelitian ini memiliki 6 hipotesis yang diajukan untuk meneliti praktik manajemen laba perusahaan di Indonesia. Hasil hipotesis-hipotesis tersebut dijelaskan sebagai berikut.

Hipotesis pertama (H1) adalah ukuran perusahaan berpengaruh signifikan terhadap manajemen laba. Dari hasil pengujian analisis regresi diperoleh nilai t hitung sebesar 2,403 dengan tingkat signifikansi sebesar 0,018 $(\mathrm{p}<0,05)$ maka variabel ukuran perusahaan berpengaruh positif secara signifikan terhadap manajemen laba yang berarti H1 diterima.

Hipotesis kedua (H2) adalah ukuran dewan komisaris berpengaruh signifikan terhadap manajemen laba. Dari hasil pengujian analisis regresi diperoleh nilai t hitung sebesar 2,566 dengan tingkat signifikansi sebesar $0,012(\mathrm{p}<0,05)$ maka variabel ukuran dewan komisaris berpengaruh positif secara signifikan terhadap manajemen laba yang berarti H2 diterima.

Hipotesis ketiga (H3) adalah keberadaan komite audit berpengaruh signifikan terhadap manajemen laba. Dari hasil pengujian analisis regresi diperoleh nilai t hitung sebesar 0,649 dengan tingkat signifikansi sebesar 0,518 ( $p>0,05)$. maka variabel keberadaan 
komite audit berpengaruh positif secara tidak signifikan terhadap manajemen laba yang berati $\mathbf{H} 3$ tidak diterima.

Hipotesis keempat (H4) adalah keberadaan kualitas auditor berpengaruh signifikan terhadap manajemen laba. Dari hasil pengujian analisis regresi diperoleh nilai t hitung sebesar 0,361 dengan tingkat signifikansi sebesar 0,719 ( $p>0,05)$. maka variabel keberadaan kualitas auditor berpengaruh positif secara tidak signifikan terhadap manajemen laba yang berati $\mathbf{H} 4$ tidak diterima.

Hipotesis kelima (H5) adalah kepemilikan konstitusional berpengaruh signifikan terhadap manajemen laba. Dari hasil pengujian analisis regresi diperoleh nilai t hitung sebesar 1,651 dengan tingkat signifikansi sebesar 0,101 $(p>0,05)$. maka variabel kepemilikan konstitusional berpengaruh positif secara tidak signifikan terhadap manajemen laba yang berati $\mathbf{H 5}$ tidak diterima.

Hipotesis keenam (H6) adalah proporsi dewan komisaris berpengaruh signifikan terhadap manajemen laba. Dari hasil pengujian analisis regresi diperoleh nilai t hitung sebesar -3,068 dengan tingkat signifikansi sebesar 0,003 $(p<0,05)$ maka variabel proporsi dewan komisaris berpengaruh negatif secara signifikan terhadap manajemen laba yang berarti $\mathbf{H 6}$ diterima.

\section{Pembahasan}

Pengaruh Ukuran Perusahaan terhadap Manajemen Laba. Dari hasil perhitungan variabel ukuran perusahaan (X1) diperoleh nilai t test (thitung) sebesar -2.403 dengan tingkat signifikansi sebesar 0,018 (di bawah 0,05). Memperhatikan hasil uji t test ini, maka hipotesis 1 (H1) yang menyatakan bahwa ukuran perusahaan secara statistik mempunyai pengaruh negatif terhadap manajemen laba dapat diterima. Berdasarkan pengujian yang dilakukan, hasil penelitian ini menunjukkan bahwa ukuran perusahaan berpengaruh signifikan terhadap manajemen laba. Hasil penelitian ini tidak konsisten dengan penelitian yang dilakukan oleh Nasution dan Setiawan (2007) yang menyatakan bahwa ukuran perusahaan tidak berpengaruh secara signifikan terhadap manajemen laba. Penelitian ini konsisten dengan penelitian yang dilakukan oleh Siregar dan Utama (2005) menunjukkan bahwa ukuran perusahaan yang diukur dengan menggunakan natural logaritma nilai pasar ekuitas perusahaan pada akhir tahun berpengaruh signifikan negatif terhadap besaran pengelolaan laba, artinya semakin besar ukuran perusahaan maka semakin kecil indikasi pengelolaan labanya. Hal ini disebabkan karena perusahaan besar biasanya memiliki peran sebagai pemegang kepentingan yang luas sehingga lebih diperhatikan oleh masyarakat. Akibatnya, perusahaan akan lebih berhati-hati dalam melakukan pelaporan keuangan untuk menghasilkan laporan yang akurat.

Hubungan Ukuran Dewan Komisaris dengan Manajemen Laba. Ukuran dewan komisaris berpengaruh negatif secara signifikan $(0,012)$ terhadap tindak manajemen laba yang dilakukan dalam perusahaan perbankan, artinya perusahaan yang memiliki dewan komisaris dalam jumlah banyak maka tindak manajemen laba yang dilakukan perusahaan semakin sedikit. yang menyatakan bahwa ukuran dewan komisaris secara statistik mempunyai pengaruh negatif terhadap manajemen laba dapat diterima. Hasil analisis ini menunjukkan bahwa perubahan ukuran dewan komisaris akan memberikan kontribusi yang negatif dan signifikan terhadap perubahan manajemen laba. Hasil penelitian ini konsisten dengan penelitian Yu (2006). Hasil ini menandakan bahwa semakin besar jumlah dewan komisaris, fungsi kontrol dan service akan semakin baik karena akan semakin banyak keahlian dalam memberikan nasehat yang bernilai dalam strategi dan penyelenggaraan perusahaan. Semakin sedikit dewan komisaris, maka tindak manajemen laba makin banyak, karena sedikitnya dewan komisaris memungkinkan bagi organisasi tersebut untuk didominasi oleh pihak manajemen dalam menjalankan perannya. Hasil ini tidak konsisten dengan hasil penelitian Marihot dan Setiawan (2007) yang menyatakan bahwa ukuran dewa komisaris berpengaruh positif signifikan terhadap manajemen laba. Penelitian ini tidak konsisten dengan penelitian Midiastuty dan Machfoedz (2003) yang menyatakan bahwa ukuran dewan komisaris
Banks' Earning Management in Indonesia 
Banks' Earning

Management In

Indonesia

134 berpengaruh positif terhadap manajemen laba perusahaan secara signifikan. Penelitian ini memberi hasil yang searah juga dengan Xie, Davidson, Dadalt (2003), Yu (2006), Zhou dan Chen (2004), dan Chtourou, Bedard, dan Courteau (2001) yang menunjukkan bahwa ukuran dewan komisaris yang lebih besar mampu mengurangi manajemen laba dalam perusahaan, yang ditunjukkan dengan koefisien negatif yang signifikan.

Hubungan Keberadaan Komite Audit dengan Manajemen Laba. Dari hasil penelitian tersebut dapat disimpulkan bahwa keberadaan komite tidak berpengaruh signifikan terhadap manajemen laba. Hal ini berarti komite audit yang diukur dari persentase jumlah anggota komite audit yang berasal dari luar perusahaan belum dapat mengurangi manajemen laba yang dilakukan oleh pihak manajemen dalam suatu perusahaan. Hasil penelitian ini tidak konsisten dengan penelitian Klein (2000) memberikan bukti secara empiris bahwa perusahaan yang membentuk komite audit independen melaporkan laba dengan kandungan akrual diskresional yang lebih kecil dibandingkan dengan perusahaan yang tidak membentuk komite audit independen. Begitu juga Carcello et al. (2006) menyelidiki hubungan antara keahlian komite audit di bidang keuangan dan manajemen laba. Hasil penelitian ini menunjukkan bahwa keahlian komite audit independen di bidang keuangan terbukti efektif mengurangi manajemen laba. Namun penelitian ini konsisten dengan penelitian Wedari (2004) serta Siregar dan Utama (2005) yang menemukan bahwa keberadaan komite audit independen tidak terbukti efektif mengurangi manajemen laba. Hal ini diduga disebabkan karena pengangkatan komite audit oleh perusahaan hanya dilakukan untuk pemenuhan regulasi saja tetapi tidak dimaksudkan untuk menegakkan good corporte governance di perusahaan.

Kualitas Auditor terhadap Manajemen Laba. Berdasarkan pengujian yang dilakukan menunjukkan bahwa kualitas auditor tidak berpengaruh secara signifikan terhadap manajemen laba. Hasil penelitian ini konsisten dengan penelitian Chen et al. (2005) yang menemukan bahwa spesialisasi industri KAP belum mampu membatasi terjadinya praktik manajemen laba. Meskipun KAP tersebut diyakini sebagai pihak yang ahli dalam bidang industri tertentu, namun hal tersebut tidak bisa dijadikan sebagai pengendalian terjadinya praktik manajemen laba yang dilakukan oleh perusahaan. Namun hasil ini tidak konsisten dengan pendapat Dang et al. (2004) dalam Mirna dan Indira (2007) berpendapat bahwa KAP yang memiliki banyak klien dalam industri yang sama, akan memiliki pemahaman yang lebih dalam tentang resiko audit khusus yang mewakili industri tersebut. Namun hal ini akan membutuhkan pengembangan yang dimiliki oleh KAP spesialis industri maka diharapkan bahwa KAP spesialisasi industri cenderung membatasi manajemen laba.

Pengaruh Kepemilikan Konstitusional terhadap Manajemen Laba. Memperhatikan hasil uji $t$ test diatas, maka hipotesis 5 (H5) yang menyatakan bahwa kepemilikan institusional secara statistik tidak mempunyai pengaruh signifikan terhadap manajemen laba. Hasil dari penelitian ini mendukung penelitian yang dilakukan Suryani (2010) yang menemukan adanya pengaruh negatif signifikan kepemilikan institusonal terhadap manajemen laba. Hasil penelitian ini tidak sejalan dengan hasil penelitian yang dilakukan oleh Ridayani (2008). Selain itu, pandangan Widiatmaja (2010) mengatakan bahwa kepemilikan institusional adalah kepepemilikan yang lebih memfokuskan pada current earnings. Akibatnya manajer terpaksa untuk melakukan tindakan yang dapat meningkatkan laba jangka pendek, misalnya dengan melakukan manipulasi laba. Keberadaan investor institusional dianggap mampu menjadi mekanisme monitoring yang efektif dalam setiap keputusan yang diambil manajer karena tingkat kepemilikan institusional yang tinggi akan meninmbulkan usaha pengawasan yang lebih besar oleh pihak investor institusonal sehingga dapat menghalangi perilaku manajer yang mementingkan dirinya sendiri yang pada akhirnya dapat merugikan perusahaan.

Hubungan Proporsi Dewan Komisaris dengan Manajemen Laba. Memperhatikan hasil uji $t$ test ini, maka hipotesis yang menyatakan bahwa proporsi dewan komisaris independen secara statistik mempunyai pengaruh negatif terhadap manajemen laba 
dapat diterima. Hasil analisis ini menunjukkan bahwa perubahan proporsi dewan komisaris independen akan memberikan kontribusi yang negatif dan signifikan terhadap perubahan manajemen laba. Hal ini menunjukkan bahwa komisaris independen terbukti berpengaruh dalam mengawasi kualitas pelaporan keuangan demi membatasi manajemen laba di perusahaan. Hal tersebut disebabkan karena dengan semakin banyak anggota komisaris independen, maka proses pengawasan yang dilakukan dewan ini semakin berkualitas dengan makin banyaknya pihak independen dalam perusahaan yang menuntut adanya transparansi dalam pelaporan keuangan perusahaan, sehingga akan mengurangi kemungkinan kecurangan dalam menyajikan laporan keuangan yang dilakukan manajemen. Hasil penelitian ini konsisten dengan penelitian Palestin (2006) dan Marihot dan Setiawan (2007) yang menyatakan bahwa proporsi dewan komisaris berpengaruh negatif terhadap praktek manajemen laba di perusahaan.

\section{PENUTUP}

Penelitian ini menguji pengaruh mekanisme corporate governance terhadap manajemen laba pada industri perbankan yang terdaftar di BEI periode 2016-2018. Mekanisme corporate governance diproksikan dengan ukuran perusahaan, ukuran dewan komisaris, keberadaan komite audit, kualitas auditor, kepemilikan institusional, dan proporsi dewan komisaris. Berdasarkan hasil pembahasan pada bab empat serta hasil pengujian hipotesis, maka dapat dperoleh beberapa kesimpulan yang dapat dikemukakan yaitu sebagai berikut. Dari hasil pengujian regresi menunjukkan bahwa ukuran perusahaan berpengaruh signifikan terhadap manajemen laba. Artinya semakin besar ukuran perusahaan maka semakin kecil indikasi pengelolaan labanya. Hal ini disebabkan karena perusahaan besar biasanya memiliki peran sebagai pemegang kepentingan yang luas sehingga lebih diperhatikan oleh masyarakat. Akibatnya, perusahaan akan lebih berhati-hati dalam melakukan pelaporan keuangan untuk menghasilkan laporan yang akurat. Dari hasil pengujian regresi menunjukkan bahwa komposisi dewan komisaris berpengaruh signifikan terhadap manajemen laba. Hal ini berarti peranan dewan komisaris dapat meningkatkan kualitas laba dengan membatasi tingkat manajemen laba melalui fungsi monitoring atas pelaporan keuangan.

Dari hasil pengujian regresi menunjukkan bahwa komposisi komite audit tidak berpengaruh signifikan terhadap manajemen laba. Ini mengindikasikan bahwa banyak sedikitnya anggota komite audit yang berasal dari luar perusahaan tidak berdampak pada manajemen laba yang dilakukan perusahaan. Hal ini disebabkan karena pengangkatan komite audit oleh perusahaan hanya dilakukan untuk pemenuhan regulasi saja tetapi tidak dimaksudkan untuk menegakkan Corporte Governance di perusahaan. Dari hasil pengujian regresi menunjukkan bahwa kualitas audit dengan proksi spesialisasi industri KAP tidak berpengaruh signifikan terhadap manajemen laba. Ini mengindikasikan bahwa semakin ahli KAP terhadap industri tertentu maka belum tentu baik audit yang dilakukan perusahaan tersebut. sehingga manajemen laba kemungkinannya kecil untuk terdeteksi. Dari hasil pengujian regresi menunjukkan bahwa kepemilikan institusional tidak berpengaruh signifikan terhadap manajemen laba. Hal ini dikarenakan pada umumnya investor institusi tidak menjalankan perannya secara efektif sebagai sophisticated investors yang dapat melakukan pengawasan atau monitoring terhadap kinerja manajemen untuk membatasi manajemen dalam mengambil tindakan atau kebijakan yang akan berdampak pada tindakan manajemen laba, jadi hasil pengujian regresi menyatakan bahwa kepemilikan institusional tidak berpengaruh terhadap manajemen laba.

Dari hasil pengujian regresi menunjukkan bahwa proporsi dewan komisaris berpengaruh kearah negative secara signifikan terhadap manajemen laba Yang berarti banyaknya jumlah anggota komisaris independen dalam perusahaan berhasil mengurangi manajemen laba yang terjadi. Keterbatasan yang terdapat dalam penelitian ini antara lain:

1.Periode penelitian hanya sebatas tahun 2016 sampai dengan tahun 2018 saja.

2.Sampel yang diperoleh hanya sedikit, yaitu 41 perusahaan.
Banks' Earning

Management in Indonesia 
Banks' Earning Management In Indonesia
3.Karakteristik dewan komisaris dan komite audit secara spesifik tidak disertakan, misalnya kompetensi, keahlian, latar belakang pendidikan, pengalaman komisaris independen dan komite audit.

\section{DAFTAR PUSTAKA}

Amanita, N. Y. (2010). "Earning Management dalam Hubungan Keagenan". Jurnal Pendidikan Akutansi indonesia.

Carcello, Joseph V. et al. 2006. "Audit Committee Financial Expertise, Competing Corporate Governance Mechanisms, and Earnings Management". http://papers.ssrn.com/.

Chen. et al. 2005. An empirical investigation of the relationship between intellectual capital and firm's market value and financial performance. Journal of Intellectual Capital. Vol 6. Issue 2.

Chtourou, SM., Jean Bedard, dan Lucie Courteau. 2001. "Corporate Governance and Earnings Management". Working Paper.

Darmawati, Deni. 2003. "Corporate Governance dan Manajemen Laba: Suatu Studi Empiris". Jurnal Bisnis dan Akuntansi, Vol. 5, No. 1, h. 47-68.

Ghozali, Imam. 2006. "Aplikasi Analisis Multivariate dengan Program SPSS. Cet. IV". Semarang: Badan Penerbit Universitas Diponegoro.

Klein, A. 2002. "Audit Committee, Board of Director Characteristic, and Earnings Management". http://papers.ssrn.com/.

Midiastuty, P., dan Mas'ud Machfoedz. 2003. "Analisis Hubungan Mekanisme Corporate Governance dan Indikasi Manajemen Laba". Simposium Nasional Akuntansi VI.

Nasution, M., dan Doddy Setiawan. 2007. "Pengaruh Corporate Governance Terhadap Manajemen Laba Di Industri Perbankan Indonesia". Simposium Nasional Akuntansi X.

Palestin, Shatila Halima. 2006. "Analisis Pengaruh Struktur Kepemilikan, Praktik Corporate Governance dan Kompensasi Bonus terhadap Manajemen Laba".

Praptitorini, Dyah dan Indira Juniarti. 2007. Analisis Pengaruh Kualitas Audit, Debit Default, dan Opinion Shopping Terhadap Penerimaan Opini Going Concern. Simposium Nasional Akuntansi X. Makasar.

Ridayani, Farikha Alifiyah. 2008. "Analisa Variabel-Variabel Corporate Governance yang Berpengaruh Terhadap Manajemen Laba. Universitas Jember".

Setiawati, L. (2000). "Pengaruh Komite Audit Terhadap Kualitas Laba".Journal Ekonomi dan Bisnis Indonesia vol 15 . 424-441.

Suaryana, A. (2001).

Suryani, Indra Dewi. 2010. "Pengaruh Mekanisme Corporate Governance dan Ukuran Perusahaan Terhadap Manajemen Laba pada Perusahaan Manufaktur yang Terdaftar di BEI". Universitas Diponegoro.

Veronica, Sylvia dan Utama, Sidharta. 2005. "Pengaruh Struktur Kepemilikan, Ukuran Perusahaan dan Praktik Corporate Governance Terhadap Pengelolaan Laba (Earnings Management)". Simposium Nasional Akuntansi VIII. Solo.

Wedari, L.K., 2004. "Analisis Pengaruh Proporsi Dewan Komisaris dan Keberadaan Komite Audit Terhadap Manajemen Laba". Simposium Nasional Akuntansi VII.

Widiatmaja, Bayu Fatma. 2010. "Pengaruh Mekanisme Coperative Governace Terhadap Manajemen Laba dan Konsekuensi Manajemen Laba Terhadap Kinerja Keuangan". Skripsi. Universitas Diponegoro

Yu, Frank. 2006. "Corporate Governance and Earnings Management". Working Paper

Yusuf, M. (2017). "Pengaruh mekanisme good corporate governance terhadap manajemen laba". jurnal revisi akutansi dan keuangan. 